\title{
Fabrication Of Aquaponic System For Integrated Freshwater Fish And Vegetables Cultivation
}

\author{
Yohandri and Zulhendri Kamus \\ Jurusan Fisika, Fakultas Matematika dan Ilmu Pengetahuan Alam, Universitas Negeri Padang Jl. Prof. Dr. Hamka Air \\ Tawar, Indonesia \\ *yohandri.unp@gmail.com,
}

Diterima 10 Desember 2019, Disetujui 14 November 2020, Dipublikasikan 30 November 2020

\begin{abstract}
The Community Partnership Program (PKM) activity has been carried out in Nagari Sunua, Padang Pariaman District, West Sumatra. As for Sunua's diversity, many young people drop out of school and do not have permanent jobs. This activity aims to provide training in the manufacture of aquaponic systems that combine freshwater fish cultivation with vegetable cultivation simultaneously. Partners will be given training on how to use freshwater aquaculture pond water to grow vegetables. Pool water will be flowed in the pipes where the vegetable seeds are grown. Pond water becomes fertilizer and nutrition for vegetables. Water that has passed through vegetables in the next pipe will be flowed back into the pond. This aquaponic cultivation pattern is very beneficial because it can produce vegetables and fish simultaneously in one activity. This can be a new type of business for partner groups that have not. In general, these activities can be carried out well and increase the knowledge and skills of the members of the partners involved.
\end{abstract}

Keywords - aquaponic, freshwater fish, vegetables, cultivation

\section{Pendahuluan}

Kotobaru berada di Kecamatan X Koto Kabupaten Tanah Datar Provinsi Sumatera Barat.Daerah ini merupakan salah satu pusat penghasil sayur-sayuran dan umbi-umbian di Sumatera Barat. Kondisi geografis Kecamatan XKoto yang berbentuk pegunungan dan terdapat banyak lahan pertanian yang dapat dipergunakan untuk bercocok tanam membuat hasil pertanian di daerah ini melimpah ruah. Hampir setiap hari dihasilkan ratusan ton sayuran dari daerah ini yang dapat memenuhi kebutuhan untuk wilayah Sumatera Barat, bahkan dijual ke luar daerah sekitarnya seperti Jambi, Pekan Baru dan daerah lainnya. Hal ini dapat menggambarkan bahwa Sektor pertanian memberikan andil cukup besar dalam perekonomian masyarakat yang tinggal di daerah ini

PKM kelompok budidaya ikan air tawar dan sayuran terintegrasi dengan sistem aquaponik di Sumatera Barat melibatkan satu mitra di Kabupataen Padang Pariaman. Pemilihan lokasi ini berdasarkan permintaan dari kelompok masyarakat yang membutuhkan kemitraan dalam mengembangkan keterampilan dan meningkatkan penghasilan mereka. Lokasi mitra berada di Korong Kampung Aur, Nagari Sunua, Kecamatan Nan Sabaris Kabupaten Padang Pariaman. Lokasi mitra ini berjaran sekitar $40 \mathrm{~km}$ dari Universitas Negeri Padang sebagai lokasi tim pengusul yang dapat ditempuh dalam waktu 1 jam perjalanan darat

Kondisi mitra di Nagari Sunua, banyak pemuda yang putus sekolah atau hanya mengenyam pendidikan sampai tingkat Sekolah Menengah 
Atas (SMA). Secara umum banyak pemuda usia produktif namun tidak memiliki pekerjaan secara tetap. Sebagian pemuda bekerja secara serabutan karena tidak memiliki keterampilan yang memadai untuk membuka suatu usaha. Kelompok pemuda ini dapat dikategorikan sebagai kelompok yang tidak produktif secara ekonomi. Kegiatan seharihari kelompok pemuda ini banyak dihabiskan nongkrong di warung jika tidak mendapatkan pekerjaan. Kondisi ini tentu perlu mendapatkan perhatian serius agar kelompok pemuda ini memiliki kegiatan yang lebih produktif dan memperoleh pendapatan yang layak. Hasil diskusi menunjukan bahwa kelompok pemuda ini memiliki keinginan untuk bekerja dan memiliki ekonomi yang baik. Namun minimnya keterampilan dan terbatasnya lapangan kerja sangat sukar untuk mendapatkan pekerjaan tetap dengan hasil yang memadai.

Berdasarkan analisis situasi yang ada pada mitra ini, maka tim merasa tergerak untuk melakukan sesuatu yang dapat memecahkan masalah yang dihadapi oleh mitra. Dalam kegiatan ini solusi yang akan ditawarkan adalah memberikan pelatihan budidaya ikan air tawar dan sayuran terintegrasi dengan sistem aquaponik. Teknologi aquaponik sangat menguntungkan dan mudah untuk dikelola karena adanya proses saling menguntungkan antara ikan yang dibudidayakan dengan sayuran [1-2]. Disamping itu, sistem teknologi aquaponik juga tidak memerlukan lahan yang besar karena dapat dibangun dengan sistem bertingkat [3] seperti terlihat pada Gambar 1 berikut ini.

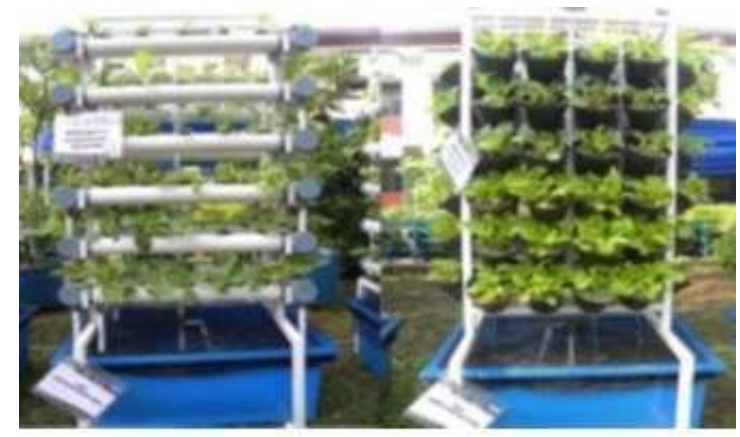

Gambar 1 Contoh teknologi aquaponik yang dikembangkan oleh BPTP [3]

Berdasarkan teknologi yang ada pada aquaponik, maka tim akan memberikan pengetahuan dan keterampilan kepada mitra
Fokus dari kegiatan diarahkan pada peningkatan penegetahuan tentang teknologi aquaponik, keterampilan membuat sistem aquaponik, serta pengetahuan tentang budidaya ikan air tawar dan sayuran

\section{METODE}

Untuk merealisasikan membuat system aquaponik, pelaksanaan kegiatan PKM ini dilakukan melalui lima tahapan. Tahapan yang dilaksanakan mulai dari tahap penjajakan sampai dengan dihasilkannya sistem aquaponik yang dapat digunakan oleh kelompok tani. Tahap-tahap pelaksanaan kegiatan ini antara lain

\subsection{Tahap survey atau penjajakan}

Dalam tahap ini dilakukan penjajakan dan penentuan lokasi kegiatan pengabdian. Disamping itu, juga akan dijajaki kondisi dan pengetahuan awal peserta tentang teknologi aquaponik untuk mengukur efektivitas program diakhir kegiatan. Untuk mengukur kemampuan awal peserta digunakan angket yang akan diisi oleh semua anggota mitra.

\subsection{Orientasi dan Diskusi}

Orientasi dan diskusi dilakukan untuk mengidentifikasi permasalahan dan keterbatasan yang ada pada kelompok mitra dan mendiskusikan solusi yang dapat dilakukan untuk mengatasi masalah tersebut. Disamping itu, juga disusun rencana dan jadwal kegiatan bersama mitra.

\subsection{Tahapan persiapan}

Dalam tahap persiapan pelaksanaan ini ada beberapa kegiatan yang akan dilakukan. Kegiatankegiatan tersebut antara lain, mengurus masalah perizinan pelaksanaan kegiatan, pemesanan komponen dan bahan pendukung untuk pembuatan kolam terpal plastik dan sistem aquaponik, penyiapan materi yang akan diberikan kepada mitra, meminta kesedian beberapa pakar dan praktisi yang akan dilibatkan dalam kegiatan ini. 


\subsection{Tahapan pelaksanaan}

Pada tahap pelaksanaan ini, kelompok tani mitra akan diberikan pengetahuan tentang budidaya ikan air tawar dan sayuran terintegrasi dengan sistem aquaponik. Setalah diberi pengetahuan sistem aquaonik, peserta dari kelompok mitra akan diberi pelatihan cara membuat kolam terpal dan sistem aquaponic yang didampingi oleh beberapa orang teknisi.

Disamping itu, pengetahuan tentang cara memproduksi dan pemasaran ikan air tawar dan sayuran juga akan diberikan kepada mitra oleh pakar dan praktisi. Secara sederhana beberapa kegiatan kunci dalam pelaksanaan PKM adalah

- Perancangan model sistem aquaponik yang sesuai dengan kondisi dan kebutuhan dari kelompok mitra.

- Mengimplementasikan desain atau model yang telah dibuat dalam bentuk alat system aquaponik menggunakan pipa PVC

- Melakukan uji coba sistem aquaponic dalam skala laboratorium untuk perbaikan dan penyempurnaan peralatan sebelum disosialisasikan kepada mitra.

- Melakukan beberapa pelatihan kepada anggota kelompok mitra yang meliputi:

- Pelatihan pembuatan sistem aquaponic secara sederhana

- Pelatihan penggunaan dan perawatan sistem aquaponik

\subsection{Tahapan monitoring}

Tahapan ini berupa kegiatan pendampingan dalam bentuk monitoring dan evaluasi atas pelaksanaan kegiatan pengabdian yang telah dilakukan. Kegiatan ini dilakukan bersama-sama oleh tim pengusul dan mitra dengan jadwal pelaksanaan sesuai dengan yang telah disepakati bersama.

Secara rinci tahapan kegiatan, jenis kegiatan, alokasi waktu dan tempat pelaksanaan kegiatan dapat diperhatikan dalam Tabel 2

Tabel 2. Tahap-tahap kegiatan dan tempat pelaksanaan

\begin{tabular}{|c|c|c|c|}
\hline $\begin{array}{l}\text { Tahap } \\
\text { Kegiata } \\
n\end{array}$ & $\begin{array}{l}\text { Jenis } \\
\text { Kegiatan }\end{array}$ & $\begin{array}{l}\text { Alokas } \\
\text { i } \\
\text { Waktu }\end{array}$ & Tempat \\
\hline I & $\begin{array}{l}\text { Survey atau } \\
\text { penjajakan }\end{array}$ & 10 jam & $\begin{array}{l}\text { (Tempat } \\
\text { mitra) } \\
\text { Kanagarian } \\
\text { Sunua, Kab } \\
\text { Padang } \\
\text { Pariman }\end{array}$ \\
\hline II & $\begin{array}{l}\text { Orientasi } \\
\text { dan Diskusi }\end{array}$ & $6 \mathrm{jam}$ & $\begin{array}{l}\text { Laboratoriu } \\
\mathrm{m} \text { Fisika } \\
\text { FMIPA UNP }\end{array}$ \\
\hline III & $\begin{array}{l}\text { Tahapan } \\
\text { persiapan }\end{array}$ & 30 jam & $\begin{array}{l}\text { Laboratoriu } \\
\text { m Fisika } \\
\text { FMIPA UNP }\end{array}$ \\
\hline IV & $\begin{array}{l}\text { Tahapan } \\
\text { Pelaksanaa } \\
\text { n }\end{array}$ & 40 jam & $\begin{array}{l}\text { (Tempat } \\
\text { mitra) } \\
\text { Kanagarian } \\
\text { Sunua, Kab } \\
\text { Padang } \\
\text { Pariman }\end{array}$ \\
\hline V & $\begin{array}{l}\text { Survey } \\
\text { atau } \\
\text { penjajakan }\end{array}$ & 10 jam & $\begin{array}{l}\text { (Tempat } \\
\text { mitra) } \\
\text { Kanagarian } \\
\text { Sunua, Kab } \\
\text { Padang } \\
\text { Pariman }\end{array}$ \\
\hline Jumlah & & $\begin{array}{l}100 \text { ja } \\
\text { kegiata }\end{array}$ & $=15$ hari \\
\hline
\end{tabular}

\section{Hasil Dan Pembahasan}

Pelaksanaan kegiatan pengabdian dibagi atas beberapa tahapan sesuai dengan jadwal yang telah disusun. Hampir semua tahapan yang telah direncanakan dapat dilaksanakan dengan baik. Tahapan kegiatan pengabdian ini meliputi perancangan, pembuatan, pengujian dan pelatihan kepada mitra kelompok tani. Secara lebih rinci hasil capaian tiap tahap diuraikan dalam bagian berikut.

\subsection{Hasil Kegiatan \\ a. pembuatan system hidroponik}

Untuk mengembangan system aquaponik, langkah awal adalah membuat system hidroponik. Desain alat dibuat berdasarkan hasil diskusi 
dengan mitra, kebutuhan teknis, serta pertimbangan lainnya. Melalui desain dapat tergambar rencana cara kerja sistem dan

memudahkan dalam melakukan pembuatan. Gambar 2 adalah desain system aquaponik yang dibuat untuk mitra

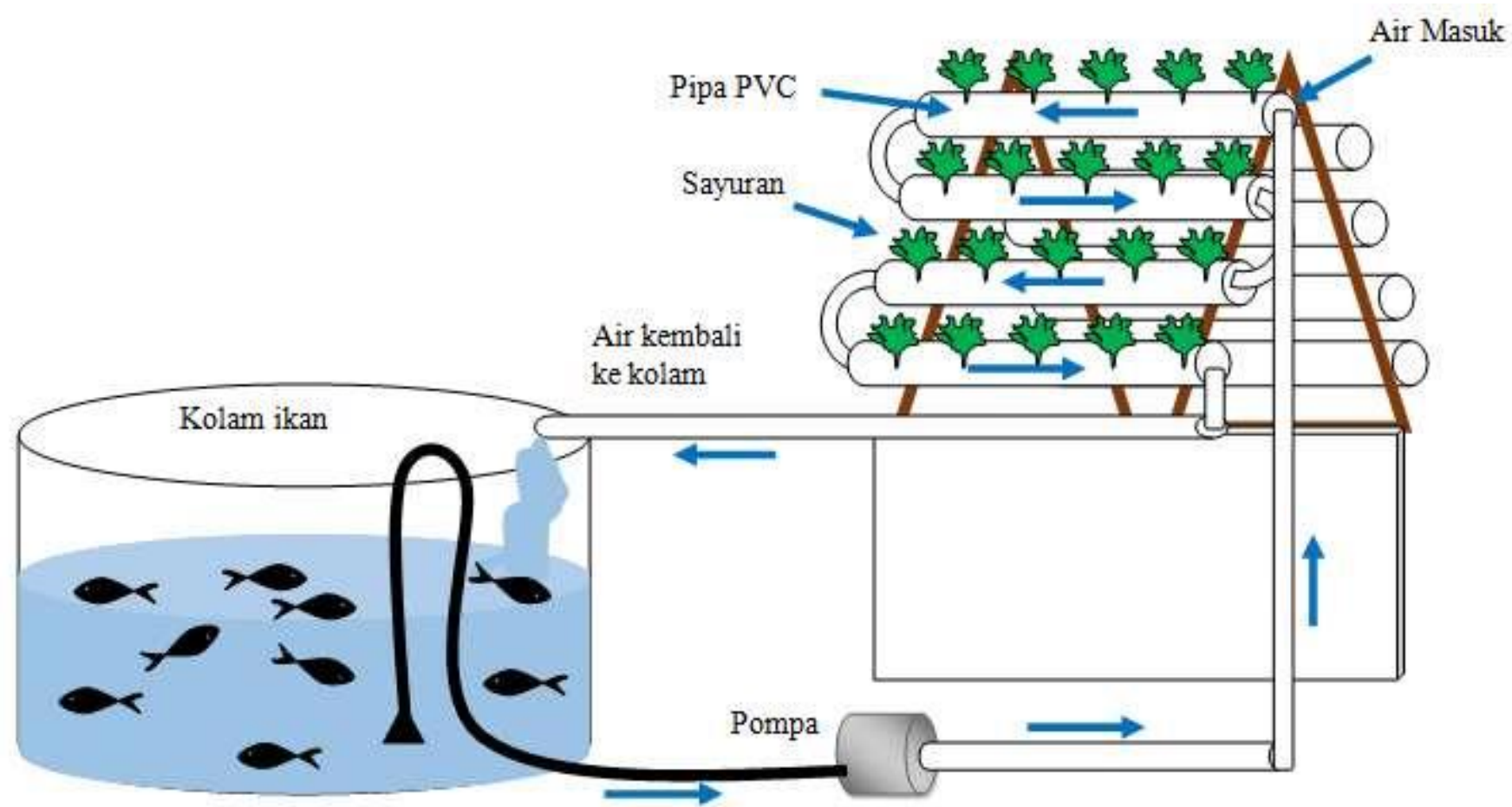

Gambar 2. Rancangan system aquaponik budidaya sayuran dan ikan air tawar terintegrasi

\section{b. Tahap pelatihan pembuatan sistem}

Tahap pembuatan alat dilakukan berdasarkan desain atau rancangan alat yang sudah dibuat pada tahap sebelumnya. Kegiatan dalam tahap ini diawali dengan menginventarisasi kebutuhan bahan dan peralatan. Setelah daftar kebutuhan diperoleh, maka mulai dilakukan pembelian dan pengadaan barang. Proses kegiatan kemudian dilanjutkan pada pembatan bagian demi bagian dari alat yang direncanakan. Dalam gambar berikut ditampilkan hasil pembuatan system aquaponic

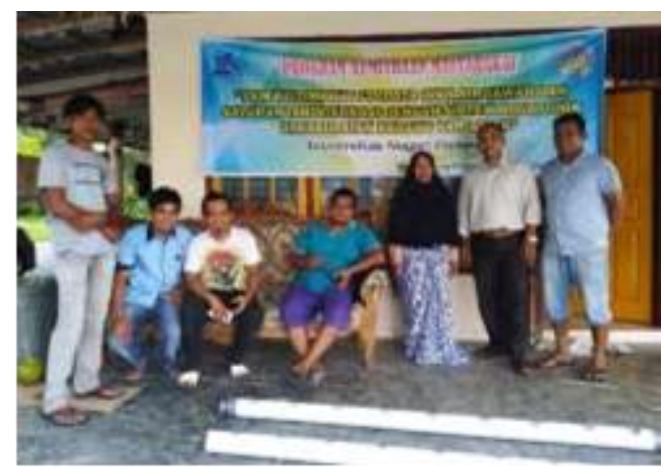

Gambar 3. Foto ketua pelaksana dan tim mitra 


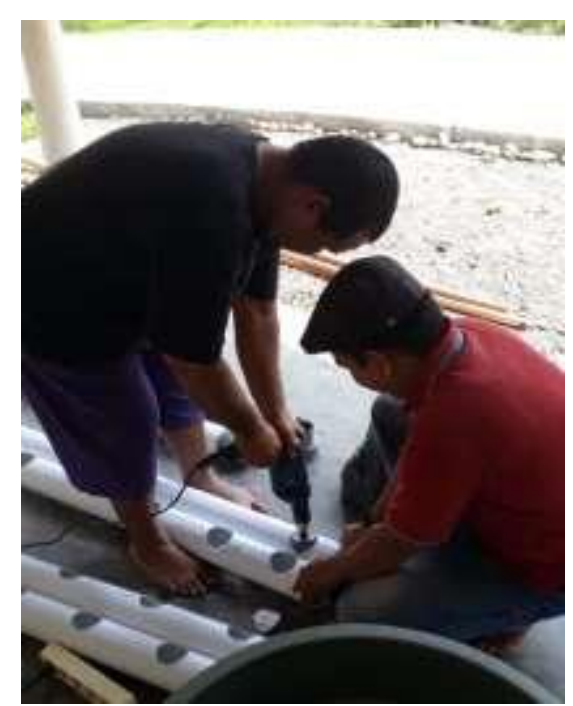

Gambar 4. Proses pembuatan lubang untuk hidroponik

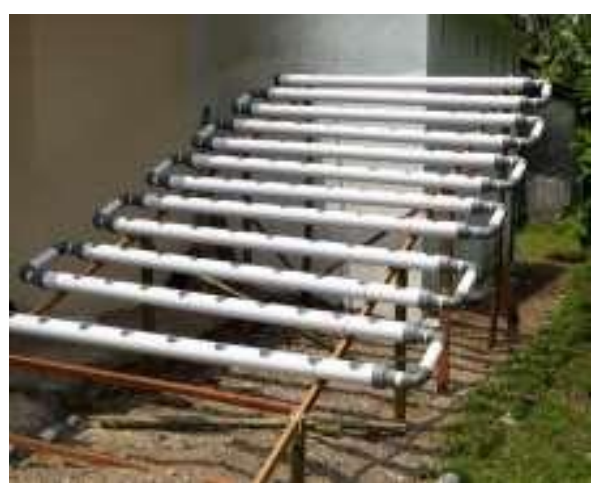

Gambar 5. Hasil pembuatan system hidroponik

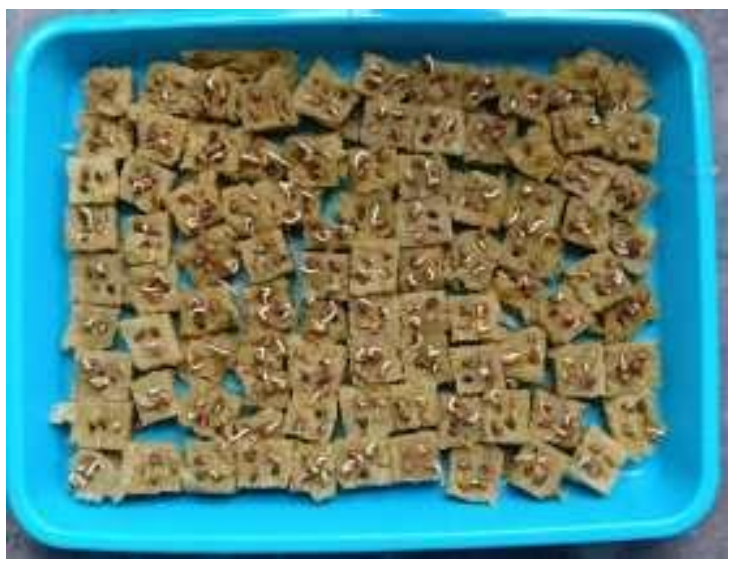

Gambar 6. Proses pembibitan sayuran kangkung

\section{c. Observasi Pelaksanaan Kegiatan}

Untuk mengetahui efektivitas dan manfaat kegiatan ini bagi peserta maka dilakukan beberapa kegiatan observasi. Observasi yang dilakukan meliputi uji pengetahuan peserta tentang system aquaponik yang dibuat, tanggapan peserta terhadap sistem dan uji kepraktisan system menurut peserta. Bedasarkan hasil observasi diperoleh tanggapan peserta sebagai berikut.

\section{Uji pengetahuan tentang sistem}

Untuk melihat efektivitas kegiatan ini dilakukan uji pengetahuan sebelum dan sesudah kegiatan dilaksanakan. Uji ini terdiri atas beberapa soal yang berhubungan dengan system aquaponik. Dengan pertanyaan yang sama antara sebelum kegiatan dengan sesudah kegiatan dapat diperoleh gambaran tentang perubahan pengetahuan peserta setelah

mengikuti kegiatan pelatihan. Berdasarkan hasil uji penguasaan materi peserta terhadap system aquaponik sebelum kegiatan diperoleh rata-rata sekitar 30\%. Setelah kegiatan dilaksanakan penguasaan materi peserta mengalami peningkatan menjadi $85 \%$. Hal ini mengindikasikan pelaksanaan kegiatan ini memberikan konstribusi terhadap peningkatan penguasaan materi peserta terhadap system aquaponik yang telah dibuat.

\section{Uji Kepraktisan penggunaan sistem}

Berdasarkan uji coba terhadap penggunaan system aquaponic, semua peserta

diminta tanggapanya terhadap kepraktisan dari sistem. Hal ini sangat penting diketahui karena menentukan apakah sistem yang sudah dibuat mudah untuk dioperasikan di lapangan. Berdarkan data angket yang diseber ke peserta diperoleh tingkat kepraktisan alat adalah sekitar

4,5 dari skala 5. Berdasarkan hasil ini dapat disimpulkan system aquaponik cukup praktis

untuk digunakan di lapangan. Namun masih terdapat beberapa cacatan terhadap system aquaponic yang dikembangkan. Diantaranya 
adalah, ari kolam tidak dapat langsung digunakan saat ikan baru dimasukan dan pengukuran kulitas air masih dilakukan secara manual. Temuan ini menjadi bahan evaluasi dalam penyempurnaan system aquaponic dimasa yang akan datang.

\subsection{Pembahasan}

Berdasarkan hasil kegiatan yang telah dilakukan dapat dikemukakan bahwa proses pelaksanaan kegiatan tahap demi tahap dapat dilaksanakan dengan baik. Pada tahap perancangan telah berhasil dikemukan desian system aquaponik yang dapat diajdikan referensi bagi kelompok pemuda dalam mengembangkan system aquaponic secara mandiri. Sementara itu, tahaptahap pembuatan juga dipaparkan dengan jelas dan mudah diikuti oleh peserta. Kegiatan pelatihan pada peserta juga memberikan konstribusi yang positif terhadap peserta berdasarkan hasil uji materi dan angket yang telah disebar. Terlihat adanya peningkatan yang signifikan terhadap penguasaan materi peserta sebelum dengan sesudai kegiatan pelatihan ini diadakan. Dalam hal kepraktisan system aquaponik, hampir semua peserta menilai bwahwa system yang telah dikembangkan cukup praktis walaupun ada beberapa catatan yang perlu disempurnakan. Dengan demikian dapat dikatakan pelaksanaan kegiatan pengabdian ini member arti yang positif terhadap mitra yang terlibat dalam kegiatan ini.

\section{Kesimpulan}

Secara umum kegiatan pengabdian ini telah berhasil dilaksanakan mulai dari tahap perancangan sampai pada tahap pelatihan peserta mitra. Berdasarkan hasil yang telah dicapai, dalam kegiatan ini dapat dikemukakan beberapa disimpulkan sebagai berikut: Semua tahapan pembuatan alat dapat dengan mudah diikuti oleh peserta mulai dari perancangan. Pembuatan dan tahap uji coba. Dalam kegiatan pelatihan peserta telah menerima materi untuk meningkatakan pengetahuan yang meliputi teknologi tepat guna dalam bidang budidaya sayuran dan ikan air tawar. Hasil uji pengetahuan peserta menunjukan terjadi peningkatan yang positif yaitu dari ratarata sekitar $30 \%$ manjadi $85 \%$ setelah kegiatan pengabdian ini dilaksanakan. Sistem yang dikembangkan dinilai sangat praktis untuk dioperasikan dengan nilai kepraktisan 4,5 dari sakala 5

\section{Ucapan Terima Kasih}

Kegiatan Pengabdian kepada Masyarakat ini terselenggaran bekat dungan dari Program Kemitraan Masyarakat LP2M UNP dengan nomor kontrak 1365/UN35.13/PM/2019.

\section{Daftar Pustaka}

[1] A.N. Ristiawan, LT. Pambudi, C. Diana dan CH. Alfabetian Herjuno, 2012. Aplikasi Teknologi Aquaponic Pada Budidaya Ikan Air Tawar Untuk Optimalisasi Kapasitas Produksi, Jurnal Saintek Perikanan Vol. 8. No. 1. Halaman 46-51.

[2] Christopher Somerville, Moti Cohen, Edoardo Pantanella, Austin Stankus, and Alessandro Lovatelli, 2014, Small- scale aquaponic food production: Integrated fish and plant farming, Fisheries and Aquaculture Technical Paper, Food and Agriculture Organization of the United Nations. Rome.

[3] Nofi A. Rokhmah, Chery Soraya Ammatillah, dan Yudi Sastro, 2014. Vertiminaponik, Mini Akuaponik Untuk Lahan Sempit di Perkotaan, Buletin Pertanian Perkotaan Volume 4 Nomor 2 Halaman 14-22 